\title{
OTOMATISASI PENGUKURAN KOEFOSIEN VISKOSITAS ZAT CAIR MENGGUNAKAN GELOMBANG ULTRASONIK
}

\author{
Eka Suci Ariyanti ${ }^{(1)}$, Agus Mulyono ${ }^{(1)}$
}

\begin{abstract}
ABSTRAK: Viskositas adalah ukuran yang menyatakan kekentalan suatu cairan atau fluida. Ukuran kekentalan zat cair ini dapat ditentukan dengan memanfaatkan proses transmisi dan pantulan dari gelombang ultrasonik. Pada penelitian ini digunakan 10 sampel campuran dari 2 zat cair yang memiliki nilai kekentalan yang berbeda yaitu encer (solar) dan kental (oli EPA 90) dengan pemberian konsentrasi yang berbeda antara campuran yang satu dengan yang lain. Tujuan penelitian ini adalah untuk membuat alat pengukur viskositas zat cair secara otomatis menggunakan sensor ultrasonik. Analisis data pada pengujian pewaktu alat menunjukkan nilai KR sebesar $4.36 \%$ dan data pada pengujian alat keseluruhan KR sebesar $4.47 \%$. Hal ini karena dipengaruhi oleh beberapa faktor baik dari luar maupun faktor dalam dari komponen itu sendiri. Dengan demikian maka alat pengukur viskositas zat cair ini telah bekerja sesuai program dan dapat digunakan untuk pengukuran karena KR alat masih dibawah 5\%.
\end{abstract}

Kata kunci: Viskositas, Zat cair, Gelombang Ultrasonik

\section{PENDAHULUAN}

Bunyi dapat kita dengar karena adanya gangguan yang menjalar ke telinga kita. Karena gangguan ini, selaput kendang ditelinga kita bergetar dan getaran ini menjadi denyut listrik yang dilaporkan ke otak lewat urat syaraf pendengaran.

Batas-batas frekuensi bunyi yang dapat kita dengar yaitu terletak antara $20 \mathrm{~Hz}-$ $20.000 \mathrm{~Hz}$. Bunyi yang frekuensinya terletak antara $20 \mathrm{~Hz}-20 \mathrm{kHz}$ disebut daerah audio. Kurang dari $20 \mathrm{~Hz}$ disebut daerah infrasonik (tak dapat didengar). Lebih dari 20 $\mathrm{kHz}$ disebut daerah ultrasonik (tak dapat didengar).

Bunyi menjalar sebagai gelombang mekanik longitudinal dalam medium padat, cair dan gas. Medium gelombang bunyi adalah molekul yang membentuk bahan medium mekanik ini. Penjalaran energi di dalam medium terjadi karena satu bagian medium mengganggu bagian medium disekitarnya. Jadi bisa dikatakan juga bahwa penjalaran gelombang didalam medium tersebut terjadi karena adanya interaksi didalam medium. Makin kuat interaksi didalam medium makin cepat penjalaran gelombangnya. Selain itu, laju penjalaran gelombang juga bergantung pada inersia medium, yaitu seberapa sukar medium digerakkan. Makin besar inersia medium, makin pelan penjalaran gelombang.

Pemanfaatan gelombang ultrasonik bisa kita jumpai diberbagai bidang kehidupan antara lain: untuk pemeriksaan kualitas produksi didalam industri, mengukur dalamnya laut, mendeteksi kerusakan pada logam, mendeteksi janin dalam kandungan dan dapat

\footnotetext{
${ }^{1}$ Jurusan Fisika UIN Maulana Malik Ibrahim Malang
} 
juga digunakan untuk menghancurkan batu ginjal tanpa operasi. Melihat begitu banyaknya manfaat dari gelombang ultrasonik tersebut maka pada kesempatan ini penulis mencoba untuk mengotomatisasi proses pengukuran viskositas zat cair dengan menggunakan gelombang ultrasonik. Mengingat pada penelitian sebelumnya yang sejenis seperti yang dilakukan (mutmainnah : 2008) masih bersifat manual.

Keunggulan yang bisa didapat dengan menggunakan Metode gelombang ultrasonik ini antara lain metodenya cukup sederhana, analisa yang dilakukan relatif cepat, serta sampel yang dianalisa dalam jumlah yang kecil. Oleh karena itu, diharapkan alat ini dapat berfungsi dengan baik sehingga bisa memberikan manfaat yang lebih diantaranya lebih mudah untuk digunakan, lebih efektif dan efisien serta dapat menghasilkan data yang lebih akurat.

\section{KAJIAN TEORI}

\section{Gelombang Ultrasonik}

Gelombang adalah suatu gangguan yang menjalar dalam suatu medium. Yang dimaksud dengan medium disini adalah sekumpulan benda yang saling berinteraksi dimana gangguan itu menjalar. Sebagai contoh bunyi dapat didengar karena adanya gangguan yang menjalar ketelinga kita.

Berdasarkan daerah frekuensinya gelombang bunyi dibagi menjadi tiga, antara lain : gelombang sonik (suara) merupakan gelombang mekanik longitudinal dengan frekuensi pada ambang pendengaran manusia yaitu $20 \mathrm{~Hz}-20 \mathrm{KHz}$. Untuk frekuensi dibawah ambang pendengaran atau kurang dari $20 \mathrm{~Hz}$ disebut gelombang infrasonik dan begitu juga sebaliknya frekuensi diatas ambang pendengaran disebut gelombang ultrasonik.

Bunyi dijalarkan sebagai gelombang mekanik longitudinal yang dapat menjalar dalam medium padat, cair, ataupun gas. Pergeseran molekul zat cair karena adanya gelombang bunyi ialah pada arah longitudinal, dan harganya sebagai fungsi posisi setimbang dari molekul (x), dan waktu t diberikan oleh :

$y=A \cos (k x-\omega t)$

Dengan A adalah amplitudo getaran, k adalah bilangan gelombang, dan ${ }^{\omega}$ adalah frekuensi sudut (sutrisno, $1984: 21$ ).

\section{Viskositas}

Viskositas merupakan ukuran kekentalan fluida yang menyatakan besar kecilnya gesekan dalam fluida. Semakin besar viskositas fluida, maka semakin sulit suatu fluida untuk mengalir dan juga menunjukkan semakin sulit suatu benda bergerak didalam fluida tersebut (mutmainnah, $2008: 6$ ).

Viskositas pada jaringan muncul karena adanya tumbukan antara partikel didalam jaringan. Besarnya viskositas pada suatu jaringan ditentukan oleh suatu konstanta pembanding yang didefinisikan sebagai koefisien viskositas dan dinyatakan dengan rumus : 
$\eta=\frac{F l}{v S}$

$$
\text { dengan } \begin{aligned}
\eta & =\text { koefisien viskositas }\left(\mathrm{N} . \mathrm{s}^{\mathrm{m}^{-2}}\right) \\
\mathrm{F} & =\text { gaya tumbukan antar molekul }(\mathrm{N}) \\
v & =\text { kecepatan partikel dalam jaringan }\left(\mathrm{m} . \mathrm{s}^{-1}\right) \\
l & =\text { jarak tumbukan antar molekul }(\mathrm{m}) \\
S & =\text { luas permukaan jaringan }\left(\mathrm{m}^{2}\right)
\end{aligned}
$$

\section{Tranduser Ultrasonik}

Dalam perancangan alat ini digunakan dua buah tranduser yaitu tranduser transmitter sebagai pemancar gelombang ultrasonik kedalam bahan yang akan diukur besar viskositasnya dan tranduser receiver atau tranduser penerima yang nantinya akan menerima sinyal gelombang ultrasonik dari bahan tersebut.

\section{Multivibrator stabil}

Segolongan rangkaian berkeadaan dua yang berguna untuk menghasilkan pulsa dan gelombang segi panjang (gelombang kuadrat = square wave) dinamakan multivibrator. Rangkaian ini biasanya terdiri dari sepasang pengeras yang dikopel satu sama lain dalam sebuah susunan umpan balik positif, seperti terlihat pada gambar dibawah ini :

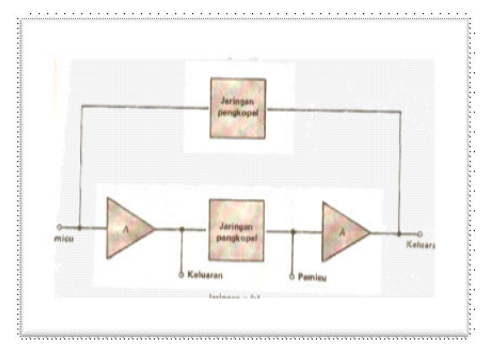

Gambar 1. Konfigurasi dasar multivibrator

Setiap pengeras dibentuk dari sebuah tahap dasar dari jenis yang dapat digantikan dari satu keadaan ke keadaan yang lainnya dengan menggunakan sebuah pemicu yang dipakaikan kepada salah satu pengeras tersebut. Jadi, setiap pengeras bertindak sebagai sebuah saklar dan setiap pengeras mempunyai sebuah keluaran yang tersedia.

Pulsa-pulsa jam didapatkan dari sebuah multivibrator astabil yang tak simetrik yang periodenya menghasilkan kecepatan pemilih. Amplitudo pulsa jam akan cukup untuk mempertahankan transistor dalam keadaan terputus kecuali selama intervalinterval diantara $T_{1}$ dan $T_{2}, T_{3}$ dan $T_{4}$ dan seterusnya, pada waktu mana terjadi pemilihan contoh. Pada waktu-waktu pemilihan, transistor berada dalam daerah aktif dan sinyal keluaran sebanding dengan sinyal masukan (Silaban, 1981 : 139-148)..

\section{Penguat Suara}

Dalam sistem audio, umumnya paling tidak terdiri dari tiga unit utama: 
1. Source/ sumber bunyi.

2. Amplifier/penguat bunyi, umumnya terdiri dari I unit integrated amplifier (amplifier tunggal) atau 2 unit terpisah pre-amp (penguat awal) dan power-amp (penguat akhir).

3. Loudspeaker/pengeras bunyi.

Penguat audio (amplifier) secara harfiah diartikan dengan memperbesar dan menguatkan sinyal input. Tetapi yang sebenarnya terjadi adalah, sinyal input di-replika (copied) dan kemudian di reka kembali (re-produced) menjadi sinyal yang lebih besar dan lebih kuat (Zaki, 2007:91).

\section{Sensor Suara}

Tone decoder adalah suatu rangkaian pencacah atau penerjemah sinyal. Tone decoder dapat digunakan untuk merubah input suara menjadi data digital. Pada perancangan alat ini digunakan tone decoder tipe LM567.

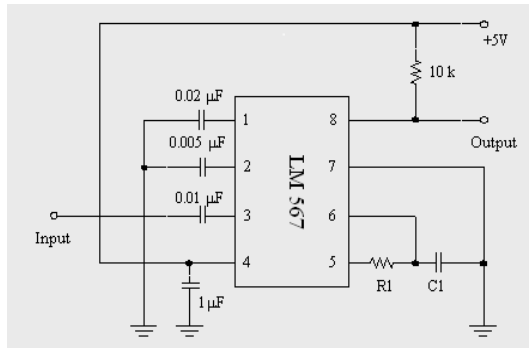

Gambar 2. IC LM567

Kelebihan dari IC LM567 antara lain (Avianto, 2008) :

1. Range frekuensi 1 sampai 20 dengan menambahkan resistor tambahan.

2. Output digital dengan keluaran arus sebesar $100 \mathrm{~mA}$.

3. Bandwidth dapat diset antara $0-14 \%$.

4. Mampu menahan noise yang masuk.

5. Mampu menahan kerusakan sinyal.

6. Kestabilan pada center frequency.

7. Center frequency dapat diset antara $0.01 \mathrm{~Hz}$ hingga $500 \mathrm{kHz}$.

\section{Mikrokontroler}

Mikrokontroler AT89S51 adalah mikrokontroler produksi Atmel yang kompatible dengan mikrokontroler Intel 8051. Didalam mikrokontroler terdapat CPU, Alu, PC, SP dan register lain yang terdapat pada mikroprosesor dan dengan tambahan perangkatperangkat lain seperti ROM, RAM, PIO, SIO, Counter dan rangkaian Clock. Mikrokontroler AT89S51 memiliki memori flash sebesar 4kB.

Konfigurasi pin mikrokontroler AT89S51

Susunan PIN Mikrokontroler AT89S51 diperlihatkan pada gambar : 


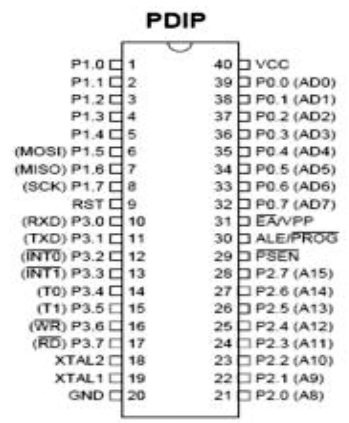

Gambar 3. Konfigurasi pin AT89S51

AT89S51 dioperasikan pada tegangan supply $+5 \mathrm{v}$, pin Vcc berada pada nomor 40 dan Vss (ground) pada pin 20 (gerbang sirkuit, 2009).

\section{LCD}

LCD (Liquid Crystal Display) adalah modul penampil yang banyak digunakan karena tampilannya menarik. LCD yang paling banyak digunakan saat ini ialah LCD M1632 refurbish karena harganya cukup murah. LCD M1632 merupakan modul LCD dengan tampilan 2x16 (2 baris x 16 kolom) dengan konsumsi daya rendah. Modul tersebut dilengkapi dengan mikrokontroler yang didesain khusus untuk mengendalikan LCD.

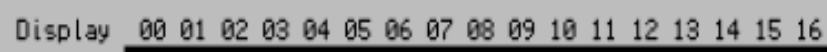

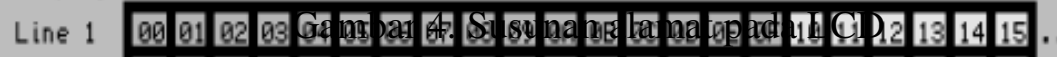

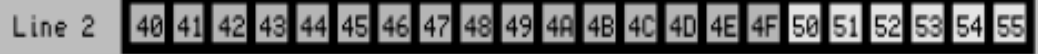

Alamat awal karakter $00 \mathrm{H}$ dan alamat akhir 39H. Jadi, alamat awal di baris kedua dimulai dari $40 \mathrm{H}$. Jika Anda ingin meletakkan suatu karakter pada baris ke-2 kolom pertama, maka harus diset pada alamat $40 \mathrm{H}$. Jadi, meskipun LCD yang digunakan $2 \times 16$ atau 2x24, atau bahkan 2x40, maka penulisan programnya sama saja (Microholic mania, 2005).

\section{METODE PENELITIAN}

\section{Diagram Blok Alat}

Pada bagian ini akan dijelaskan mengenai perancangan rangkaian dari alat pengukur viskositas zat cair, yang meliputi diagram blok rangkaian, dan mengenai perancangan perangkat lunak. Blok diagram otomatisasi alat pengukur viskositas zat cair ditunjukkan dalam gambar : 


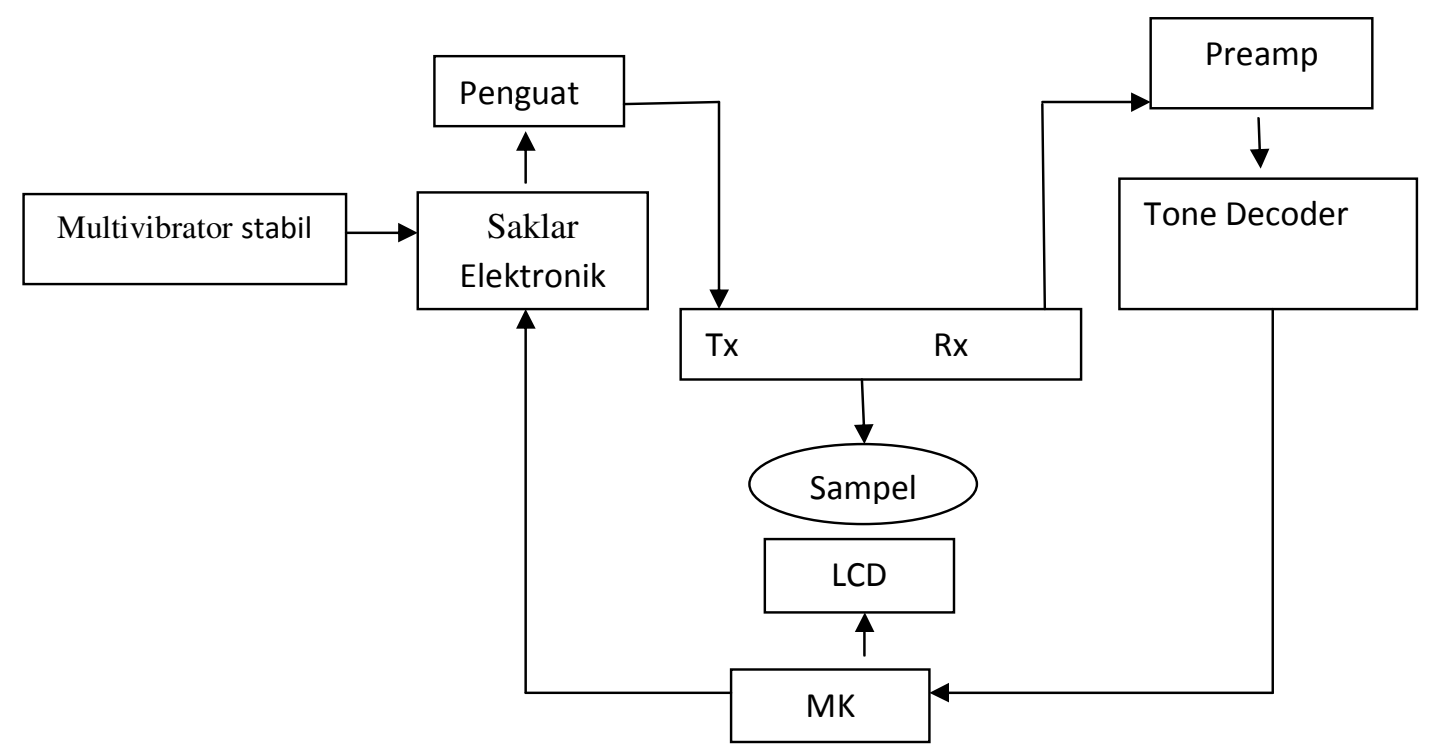

Gambar 5. Diagram otomatisasi alat pengukur viskositas zat cair

\section{Perancangan Perangkat Lunak}

Sistem perangkat keras yang dirancang menggunakan mikrokontroler sebagai pengendali utamanya tidak akan dapat bekerja jika tidak disertai dengan perangkat lunak sebagai pengatur keseluruhan system. Perangkat lunak pada rancangan ini menggunakan bahasa assembler dan untuk algoritma pemrogramannya ditunjukkan sesuai flowchart pada gambar 6 berikut :

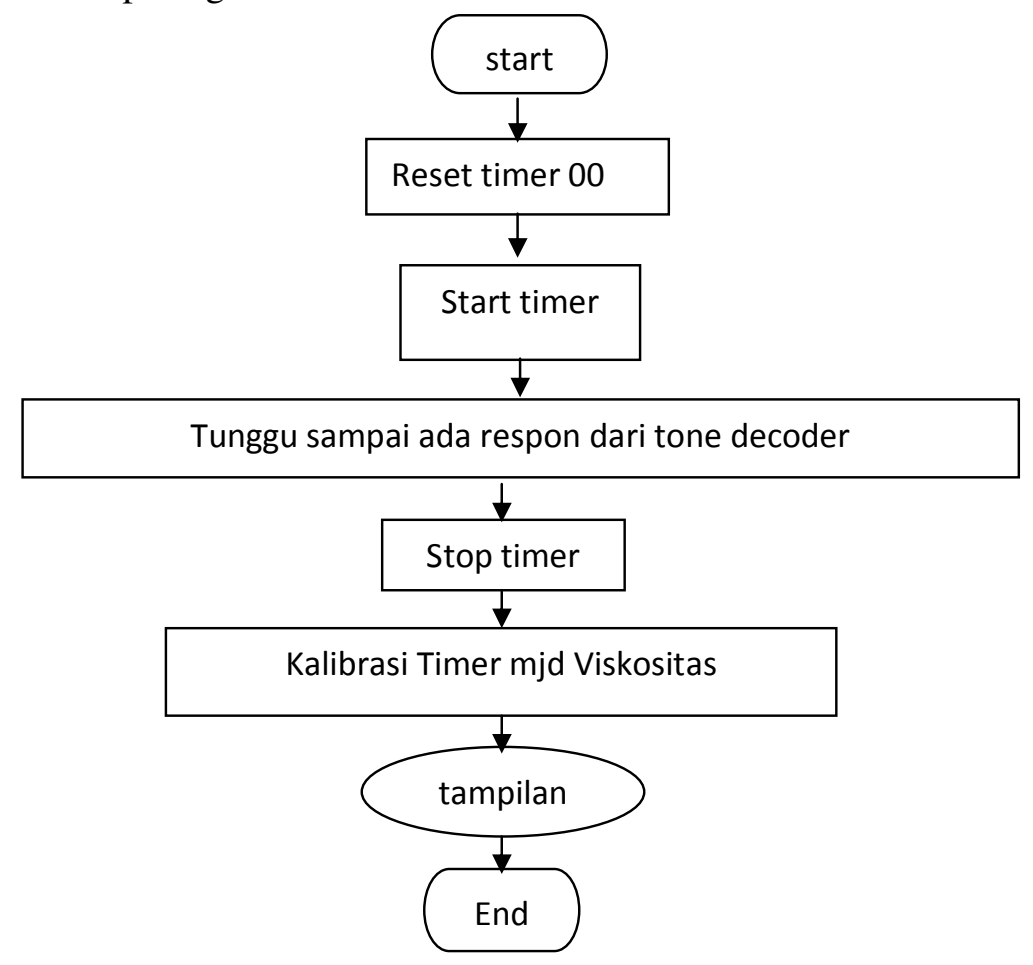

Gambar 6. Flowchart Pemrograman 


\section{HASIL DAN PEMBAHASAN}

\section{Hasil Penelitian}

Pada pengujian ini digunakan 10 sampel campuran oli dan solar dengan nilai viskositas yang berbeda-beda mulai dari yang paling encer sampai pada yang paling kental. Tahap awal pengujian dilakukan dengan mengukur nilai viskositas sampel secara perhitungan pada alat yang sudah ada sebelum kemudian diukur menggunakan alat ukur ultrasonik untuk dibandingkan hasilnya dan untuk mengetahui seberapa besar kesalahan relatif (KR) yang ditimbulkan oleh alat sehingga nantinya bisa ditentukan apakah alat ini efektif dan efisien untuk digunakan dalam pengukuran nilai viskositas zat cair. Grafik fungsi linearitas alat ditunjukkan oleh gambar berikut:

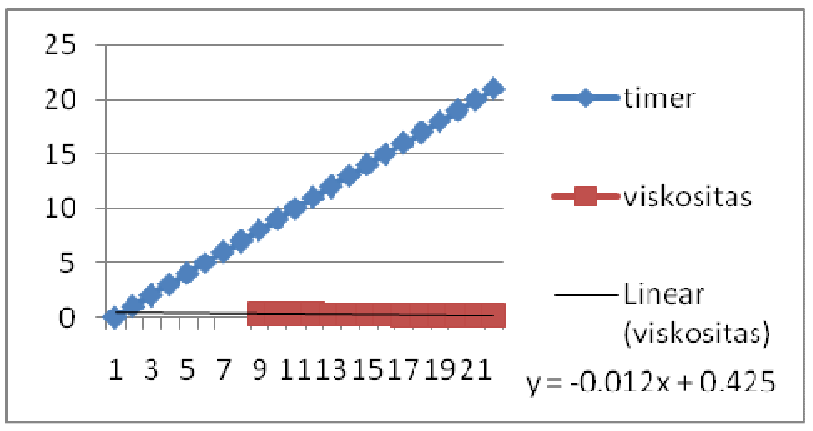

Gambar 7. Grafik fungsi linear alat

Untuk lebih jelasnya pengambilan data viskositas zat cair ditunjukkan oleh tabel berikut :

Tabel 1. Data pengukuran nilai Viskositas

\begin{tabular}{|c|c|c|c|c|}
\hline No & Campuran & $\begin{array}{l}\text { Viskositas pada alat } \\
\text { yang sudah ada } \\
(\mathrm{kg} / \mathrm{m} . \mathrm{s})\end{array}$ & $\begin{array}{l}\text { Viskositas } \\
\text { pada alat ukur } \\
\text { ultrasonik } \\
(\mathrm{kg} / \mathrm{m} . \mathrm{s})\end{array}$ & $\begin{array}{l}\text { Kesalahan } \\
\text { relatif/ KR (\%) }\end{array}$ \\
\hline 1 & A (kental) & 0.335 & 0.329 & 1.7 \\
\hline 2 & B & 0.315 & 0.317 & 0.6 \\
\hline 3 & C & 0.295 & 0.305 & 3.3 \\
\hline 4 & D & 0.255 & 0.281 & 10.1 \\
\hline 5 & E & 0.239 & 0.257 & 7.5 \\
\hline 6 & F & 0.231 & 0.245 & 6.0 \\
\hline 7 & G & 0.215 & 0.221 & 2.7 \\
\hline 8 & H & 0.207 & 0.209 & 0.9 \\
\hline 9 & I & 0.191 & 0.173 & 3.1 \\
\hline 10 & J (encer) & 0.159 & & 8.8 \\
\hline & \multicolumn{5}{l}{ \% kesalahan rata-rata } \\
\hline
\end{tabular}

Untuk analisis data pada alat ukur nilai kekentalan zat cair ini dilakukan dengan menghitung prosentase kesalahan relatif (KR) antara nilai kekentalan zat cair hasil 
perhitungan pada alat yang sudah ada dan pengukuran pada alat ultrasonik. Adapun persamaan yang digunakan adalah :

$\mathrm{KR}=\left|\frac{\eta_{\mathrm{au}}-\eta_{\mathrm{as}}}{\eta_{\mathrm{a}}} \times 10 \mathrm{n} \%\right|_{\text {atau }}$

$\%$ kesalahan rata-rata $=\frac{2 \mathrm{KR}}{n}=\frac{44.7}{10}=4.47 \%$

Berdasarkan hasil pengujian perbandingan nilai viskositas sebagaimana perhitungan dengan menggunakan persamaan diatas maka diketahui bahwa besarnya kesalahan rata-rata pada alat adalah $4.47 \%$.

\section{PEMBAHASAN}

Berdasarkan hasil penelitian melalui tekhnik pengujian komponen secara keseluruhan maka hasil yang diperoleh adalah rangkaian sensor ultrasonik, rangkaian penguat suara, rangkaian pencacah, mikrokontroler dan LCD dapat bekerja sesuai perencanaan. Setiap bagian dalam sistem ini mampu bekerja sesuai kontrol masingmasing.

Pada hasil pengujian alat didapatkan perbandingan nilai viskositas hasil pengukuran dari alat yang sudah ada dengan nilai viskositas hasil pengukuran dari alat ukur menggunakan gelombang ultrasonik. Data yang diperoleh pada alat ukur menggunakan gelombang ultrasonik menunjukkan bahwa pada sampel ke-1 menghasilkan nilai viskositas terbesar $0.329 \mathrm{~kg} / \mathrm{m} . \mathrm{s}$ dengan komposisi jumlah oli lebih banyak (lebih mendominasi) dibandingkan solar. Sedangkan data pada sampel ke-10 sebesar $0.173 \mathrm{~kg} / \mathrm{m} . \mathrm{s}$ merupakan data dengan nilai viskositas terkecil karena pada sampel ini tidak terdapat campuran oli sama sekali melainkan solar murni. Sehingga dapat disimpulkan bahwa semakin kental suatu zat cair maka akan semakin besar nilai viskositasnya.

Dengan melihat hasil nilai kesalahan rata-rata sebesar $4.47 \%$ maka dapat dikatakan pengujian alat ini berhasil dan telah bekerja sesuai program yang diinginkan karena masih memenuhi persyaratan yang telah ditentukan yaitu kesalahan rata-ratanya kurang dari 5\%. Oleh karena itu maka alat ini dapat digunakan sebagai alat ukur viskositas zat cair secara otomatis

Setiap dilakukannya suatu penelitian ataupun pengujian pasti akan terdapat beberapa faktor baik dari luar (misalnya : suhu, noise berupa suara/bunyi dari luar, kekurangtepatan dalam melakukan pencampuran sampel dan kekurangtelitian pada saat proses pengambilan data terutama pada saat melakukan pembacaan timer baik timer pada alat yang sudah ada maupun timer pada alat ukur menggunakan gelombang ultrasonik. Sedangkan faktor dari dalam (berhubungan dengan efisiensi dari komponen) yang menghambat atau mempengaruhi terhadap hasil dan jalannya pengujian yang mana hal ini nantinya akan sangat berpengaruh sekali terhadap hasil ataupun data yang dihasilkan tidak terkecuali juga terjadi pada pengujian kali ini. Namun, selama nilai kesalahan rata-rata yang didapatkan tidak melebihi dari standar yang ditentukan maka hal ini masih bisa ditolerir dan alat bisa digunakan untuk penelitian selanjutnya. 


\section{KESIMPULAN}

Berdasarkan hasil pengujian dan pembahasan pada alat pengukur nilai viskositas maka dapat diambil beberapa kesimpulan, antara lain :

Pembuatan Otomatisasi alat pengukur viskositas zat cair ini memanfaatkan sistem pantulan dari gelombang ultrasonik (dibangkitkan oleh sensor ultrasonik) yang dipancarkan pada sampel oleh tranduser transmitter dan hasil pantulan gelombangnya ditangkap kembali oleh tranduser receiver. Melalui sistem pantulan gelombang ini maka akan diketahui besarnya waktu yang dibutuhkan gelombang dalam menempuh perambatannya. Dalam pembuatan alat ini juga didukung oleh beberapa komponen elektronika lainnya seperti tone decoder sebagai pencacah sinyal, rangkaian-rangkaian penguat sinyal, mikrokontroler berfungsi sebagai pewaktu otomatis sekaligus sebagai pusat pengolah program yang mengkalibrasi nilai dari pewktu menjadi nilai viskositas serta perangkat lunak Assembler sebagai bahas program. Kemudian hasil pendeteksian alat ini akan ditampilkan oleh LCD.

Penentuan tingkat keakuratan dari alat pengukur viskositas zat cair ini dilakukan melalui perbandingan nilai viskositas yang didapat dari pengukuran pada alat ukur viskositas yang sudah ada dengan nilai hasil pengukuran pada alat ukur viskositas menggunakan gelombang ultrasonik. Berdasarkan data pada tabel 4.4 diketahui bahwa nilai kesalahan rata-rata pada alat sebesar $4.47 \%$ sehingga bisa disimpulkan alat ukur viskositas dengan menggunakan gelombang ultrasonik ini layak dijadikan sebagai alat ukur viskositas untuk zat cair.

\section{DAFTAR PUSTAKA}

[1]. Avianto, tiyo. 2008. Sensor pendeteksi suara atau tone decoder dengan LM567. http://www. Tiyo avianto.com

[2]. Elkamania team. 2007. Modul Praktikum Interface. http://www. Elka Brawijaya. Ac. Id/praktikum/tak. Php? Page 4

[3]. Gerbang Sirkuit. 2009. Arsitektur AT89S51/52 (MC S51). http://www. Gerbang sirkuit. Wordpress. Com/2009/01/16/arsitektur AT89S5152-mcs 51

[4]. Giancoli, Douglas C. 2001. Fisika jilid 1. Erlangga. Jakarta

[5]. Jatmiko, Indra. 2007. Skripsi Pengukuran Viskositas Oli menggunakan Gelombang Ultrasonik. Universitas Brawijaya. Malang

[6]. Malvino, Albert Paul, PH.D., E.E. 2004. Prinsip-prinsip Elektronika, terjemahan Ir. Alb. Joko Santoso, MT. Salemba Teknika. Jakarta

[7]. Microholic mania. 2005. Pemrograman (interface) LCD dengan Mikrokontroler AVR ATMega8535. http://www. Iddhien. Com

[8]. Mutmainnah, Siti. 2008. Skripsi Pembuatan Counter waktu pada percobaan viskositas berbasis mikrokontroler HRS8000. UIN. Malang

[9]. Nugroho, Rakhmat. 1987. Skripsi Pengukuran Modulus Elastisitas Bahan menggunakan Gelombang Ultrasonik. ITB. Bandung

[10]. Silaban, Pantur. 1981. Dasar-dasar Elektroteknik. Erlangga. Jakarta 
[11]. Sutrisno. 1984. Fisika Dasar, Gelombang dan Optik. ITB. Bandung [12]. Zaki. 2007. Cara Mudah Merangkai Elektronika Dasar Lanjutan. Absolut. Yogyakarta 